\title{
The More, The Better? - A Case History Of Audit Committee Regulations
}

\author{
Songtao Mo, Purdue University Calumet, USA \\ Yifan Shi, KPMG China, China \\ Yajing Wang, China
}

\begin{abstract}
An understanding of changing auditing regulatory environment is vital in preparing students for the challenges in the accounting profession. The revised requirements for audit committees are one of the significant changes after the Sarbanes-Oxley Act of 2002. Presenting a case history of regulatory changes for audit committees, this study requires students to critically analyze information and to conduct research on auditing topics. Meanwhile, integrating further discussion on corporate governance into auditing class can enrich students' learning experience by stimulating critical thinking.
\end{abstract}

Keywords: Audit Committee; Corporate Governance; Case History

\section{INTRODUCTION}

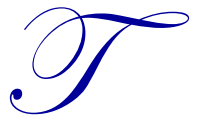

he Sarbanes-Oxley Act of 2002 (SOX) has significantly impacted the accounting profession in multiple ways. In response to the regulatory changes, accounting students need to obtain new knowledge and skills in order to meet the challenges (Alvin \& Elder, 2006). The objective of this case is to assist students to obtain a better understanding of audit committees - an important element related to audit risk.

According to Burke et al. (2006), an audit committee is defined as "a standing committee of the board of directors that is charged, at a minimum, with overseeing the integrity of the company's financial reporting process." The committees of public companies bear the responsibility of protecting shareholders. The concept of audit committees was first introduced in the 1930s, but the regulations prior to the SOX did not seem to work as expected. In the wake of the collapses of Enron, WorldCom, and other companies in the early $21^{\text {st }}$ century, Congress turned its attention to the regulations on corporate governance and audit committees. In 2002, the SOX and other related regulations were passed to further protect public interest. One of the objectives of the new legislations was to improve corporate governance by strengthening the oversight function of the audit committee and enhancing independence of audit committee members.

\section{The Pre-SOX Regulatory Development of Audit Committees}

Table 1 provides a summary of the changing requirements for audit committees. As illustrated, the regulation of audit committees was first introduced by the New York Stock Exchange (NYSE) in 1939. After the McKesson and Robbins fraud in the 1930s, the Securities and Exchange Commission (SEC) issued a recommendation to establish audit committees in public companies. The establishment of audit committees allowed stockholders an opportunity to monitor the management of listed companies.

The regulation on audit committees has been accelerated since the 1970s. The SEC amended the rules in 1974 and started to require that public companies provide disclosures on independence of audit committee members. By 1977, the NYSE began to require audit committees to be composed of independent directors. According to the requirement, audit committee members should be free from any relationship that might interfere with their responsibilities. In the same year, the SEC required disclosure of functions performed by audit committees. 
In 1988, the American Institution of Certified Public Accountants (AICPA) issued SAS 61 "Communication with Audit Committees", which was superseded by SAS 114 in 2006. SAS 61 to address the communication issues between external auditor, audit committee, and management. SAS 61 "requires the auditor to ensure that the audit committee receives additional information regarding the scope and results of the audit that may assist the committee in overseeing the financial reporting and disclosure process for which management is responsible." (AICPA, 1988). As such, representing shareholders' interests, audit committees should oversee the external auditing function. Also in 1988, the Blue Ribbon Committee (BRC) started a research project to investigate how audit committees could be more effective. The BRC report suggests that audit committees should be composed of a minimum of three financially literate members and one member with financial expertise. In 1999, based on the Blue Ribbon Committee's recommendation, the NYSE, the National Association of Securities Dealers (NASD), the SEC, and the AICPA finalized the regulatory changes for audit committees.

Nevertheless, the pre-SOX regulations and rules were not effective in preventing the collapse of such companies as Enron and WorldCom. Corporate and accounting scandals called for better methods to protect investors' interests. The investigation conducted by the U.S. Senate Permanent Subcommittee on the Enron debacle reported that the directors should be partially held responsible for Enron debacle. The report further recommended that measures should be taken to strengthen oversight over accounting practices. In addition, public companies should ensure independence of the members serving on audit committees. The emphasis placed on "oversight" and "independence" was aligned with the BRC recommendations and the 1999 regulatory changes of "free of conflicts" and "quality of financial reporting".

\section{The Sarbanes-Oxley Act of 2002}

In response to repeated corporate failures, legislators passed the SOX in 2002. The SOX was organized into eleven titles, including compliance, corporate responsibility for financial reports, disclosures in annual and periodic reports, internal control, in-time disclosure, fraud, and other important issues. The objectives of the SOX were to restore public confidence in equity market and to significantly promote corporate responsibility. The SOX increased authorities of audit committees in overseeing financial reporting processes and monitoring management decisions on financial reporting and disclosure. The major components of the SOX on audit committee reform lie in four areas - a new definition, clarified responsibilities, the composition, and updated member qualification requirements of audit committees.

\section{Definition}

SOX Section 205 defines an audit committee as "a committee (or equivalent body) established by and amongst the board of directors of an issuer for the purpose of overseeing the accounting and financial reporting processes of the issuer and audits of the financial statements of the issuer, or if no such committee exists with respect to an issuer, the entire board of directors of the issuer."

\section{Responsibility}

An audit committee's responsibilities involve overseeing financial reporting and the disclosure process, hiring independent external auditors, and performance of internal auditors. In addition, an audit committee also monitors the choice of accounting policies and principles, and discusses risk management policies and practices with management.

\section{Composition}

Audit committee members should follow the requirement of independence. Specifically, audit committee members are not allowed to accept any consulting, advisory, or other compensatory fee from management of the company or be affiliated with the company or any subsidiary. 


\section{Qualification}

An audit committee is required to have at least one financial expert. Financial experts on the committee help clarify accounting policies and judgments when committee members review corporate financial statements.

\section{SUMMARY}

The discussion of audit committee regulatory changes bears great importance to the study of corporate governance, a mechanism of protecting investors' interests. As discussed, the pre-SOX regulations and recommendations were clear on the composition and responsibilities of audit committees, which were further clarified in the SOX. Summarizing the history of audit committee requirements, this case asks the question, "Do investors need more regulations? More importantly, are more regulations leading to better regulations? “

\section{DISCUSSION QUESTIONS}

1. With increasing responsibilities in the battle against accounting scandals and frauds, audit committees have become a significant force in the corporate governance reform since the SOX. However, recent collective failures of financial institutions and the credit crisis (e.g., financial crisis in 2008) begs answers to the questions, "How could the public interest be better protected? Would more regulations serve the purpose? "

2. Based on your understanding of the development of audit committee requirements, please discuss the significance of independence requirement for audit committee members.

3. What roles do the regulatory agencies (e.g., the SEC, the PCAOB) play in enforcing the requirements for audit committees? What specific measures would you suggest to improve the effectiveness of audit committees?

4. What would you suggest to further strengthen corporate governance to protect the public interest and retain investor confidence?

\section{AUTHOR INFORMATION}

Songtao Mo, Ph.D., is an Assistant Professor of Accounting in the School of Management at Purdue University

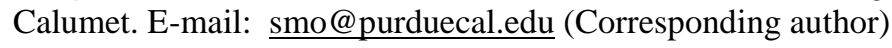

Yifan Shi received her Master of Accountancy degree in 2009.

Yajing Wang received her Master of Accountancy degree in 2009.

\section{REFERENCES}

1. American Institute of Certified Public Accountants (AICPA). (1988). SAS 61 "Communication with audit committees". Full text retrieved from http://umiss.lib.olemiss.edu:82/articles/1038084.6644/1.PDF

2. Alvin, A. \& Elder, R. J. (2006). Perspectives on auditing education after Sarbanes-Oxley. Issues in Accounting Education, 21(4), 345-362.

3. The Blue Ribbon Committee. (1999). Report and recommendations of the Blue Ribbon Committee on improving the effectiveness of Corporate Audit Committees. Retrieved from http://www.nasdaq.com/about/Blue Ribbon_Panel.pdf

4. Burke, F. M., Guy, D. M., \& Tatum, K. W. (2006). Audit Committees: A guide for directors, management, and consultants. $5^{\text {th }}$ Edition. $\mathrm{CCH}$, a Wolters Kluwer business, Riverwoods, Illinois.

5. United States Senate (2002). The role of the board of directors in Enron's Collapse. Retrieved from http://fl1.findlaw.com/news.findlaw.com/cnn/docs/enron/senpsi70802rpt.pdf

6. $\quad$ The Sarbanes-Oxley Act of 2002. H.R. 3763. The $107^{\text {th }}$ Congress, $2^{\text {nd }}$ Session. 2002.

7. Rittenber, L.E., Johnstone, K. M., \& Gramling, A. A. (2010). Auditing, A business risk approach. Mason, $\mathrm{OH}$ : South-Western Cengage Learning. 
Table 1: The Regulatory Development of Audit Committees

\begin{tabular}{|c|c|c|c|c|}
\hline Period & Requirements & Role of Audit Committee & Important Event & Enforcement \\
\hline $\begin{array}{l}1939- \\
1970\end{array}$ & $\begin{array}{l}\text { - AICPA: public companies create } \\
\text { committee made up of outside } \\
\text { directors (1967). }\end{array}$ & $\begin{array}{l}\text { - NYSE: when practical, the members should appoint a committee of non- } \\
\text { officer directors to select the external auditors (1939). } \\
\text { - SEC: outside directors nominate the external auditors (1940). } \\
\text { - AICPA: external auditors should communicate with the audit committee } \\
\text { on significant issues. }\end{array}$ & $\begin{array}{l}\text { - NYSE: endorses the concept of audit } \\
\text { committee due to the SEC's } \\
\text { investigation of Mckesson \& } \\
\text { Robbins, Inc.. (1939). }\end{array}$ & Voluntary \\
\hline $\begin{array}{l}1971- \\
1980\end{array}$ & $\begin{array}{l}\text { - SEC: endorse the establishment of } \\
\text { an audit committee (1972) } \\
\text { - NYSE: the establishment of audit } \\
\text { committee no later than } 1978 \text { as a } \\
\text { requirement to be listed on the } \\
\text { NYSE (1977) }\end{array}$ & $\begin{array}{l}\text { - SEC: audit committee is responsible for overseeing the independence of } \\
\text { the external auditor (1977 \& 1978). }\end{array}$ & $\begin{array}{l}\text { - SEC release entitled "Standing Audit } \\
\text { Committees Composed of outside } \\
\text { directors" (1972) } \\
\text { - Foreign Corrupt Practice Act (1977) }\end{array}$ & Voluntary \\
\hline $\begin{array}{l}1980- \\
2000\end{array}$ & $\begin{array}{l}\text { - SEC: all public companies should } \\
\text { have audit committees composed of } \\
\text { independent directors } \\
\text { - AMEX: all listed companies are } \\
\text { required to establish and maintain an } \\
\text { audit committee with a majority of } \\
\text { outside directors } \\
\text { - FDICIA: detailed requirements for } \\
\text { federally insured banks and other } \\
\text { depositories }\end{array}$ & $\begin{array}{l}\text { Treadway Report (1987) } \\
\text { - Audit committee should review management evaluation of the } \\
\text { independence of the external auditors when performing management } \\
\text { advisory services. } \\
\text { - Audit committee should oversee the quarterly financial reporting process. } \\
\text { - Audit committee should assure proper and coordinated involvement of } \\
\text { internal auditors in the financial reporting process. } \\
\text { - Audit committee may initiate investigations. } \\
\text { - The management should advise audit committee when seeking a second } \\
\text { opinion on a significant accounting issue. } \\
\text { Blue-Ribbon Committee } \\
\text { - The requirements of financial literary for independent directors. } \\
\text { - At least one member of the independent directors should be an } \\
\text { accounting or financial expert. }\end{array}$ & $\begin{array}{l}\text { - Treadway Commission report (1987) } \\
\text { - The Report of the National } \\
\text { Commission on Fraudulent Financial } \\
\text { Reporting (1987) } \\
\text { - Blue-Ribbon Committee: improve } \\
\text { the effectiveness of audit committees } \\
\text { - AICPA: SAS 61, Communication } \\
\text { with Audit Committees (1988) } \\
\text { - FDICI: the first US federal } \\
\text { legislation to mandate audit } \\
\text { committees. } \\
\text { - NASDAQ, NYSE, AMEX, SEC, } \\
\text { AICPA: finalize major rule changes } \\
\text { to implement recommendations of } \\
\text { the Blue Ribbon Committee. }\end{array}$ & Mandatory \\
\hline $\begin{array}{l}2001- \\
\text { present }\end{array}$ & $\begin{array}{l}\text { - Audit committees are the formal } \\
\text { "audit clients", with responsibility to } \\
\text { hire and fire its external auditors. } \\
\text { - pre-approve any nonaudit services } \\
\text { provided by external auditors; audit } \\
\text { committees must also publicly } \\
\text { report their charter and issue an } \\
\text { annual report on their activities. } \\
\text { - To have at least one financial expert } \\
\text { on the committee. }\end{array}$ & $\begin{array}{l}\text { PCAOB: } \\
\text { - Review the annual financial statements } \\
\text { - Confer with management and the external auditor about the financial } \\
\text { statements } \\
\text { - Assure that the external auditors are required to communicate under } \\
\text { auditing standards } \\
\text { - Assess that the financial statements are complete and consistent with the } \\
\text { information known to the audit committee. } \\
\text { - Assess that the financial statements reflect appropriate accounting } \\
\text { principles. }\end{array}$ & $\begin{array}{l}\text { - The SOX Act (2002) } \\
\text { - PCAOB (2002) } \\
\text { - COSO Enterprise Risk Management- } \\
\text { Integrated Framework (2004) }\end{array}$ & Mandatory \\
\hline
\end{tabular}

Note: The table is constructed based on the materials from the books and papers included in the references. The summary is intended to provide students a timeline of audit committee requirement changes. 


\section{TEACHING NOTES}

The case requires students to research auditing standards and regulations for audit committees. Students may work individually or as a group. The use of a small group (2-3 members) is highly recommended. The case can serve as an instrument for class discussion, introducing the audit functions and the history of auditing, internal control (e.g., control environment), and professional ethics (e.g., independence).

The case is designed to stimulate critical thinking beyond the textbook. Students are required to conduct research in auditing and accounting. For instance, students should incorporate contemporary issues (e.g., financial crises) in their discussion of corporate governance and audit committees. Grading will be based on how well the arguments are developed. Students are required to form an opinion and build arguments to support their opinion. The key points may include, but are not limited to, the following discussions.

Students may start the discussion with reasons leading to the ineffectiveness of the pre-SOX regulations from various perspectives. For instance, the ineffectiveness of those regulations, in part, can be attributed to the lack of regulatory enforcement and, consequently, ineffective implementation efforts by management.

As discussed, the SOX requires that audit committees oversee auditing functions, which promotes auditor independence that is vital to the public interest. So is the requirement on integrity and independence of audit committee members. While the regulations were introduced with the intent to significantly enhance public confidence, the development of audit committee requirements has demonstrated that the existence of regulations does not necessarily lead to reduced risks for investors. In other words, effective implementation of existing regulations is much more important than the mere words on paper.

The significance of effective enforcement can never be overstated. The enforcement of ethical obligations of audit committee members is also critical for corporate governance mechanism to perform at its best. Audit committee members who are independent, competent, and willing to enforce the regulations are an essential part in protecting investors. 


\section{NOTES}

